\title{
GOLDMAN, Marcio. Como funciona a democracia. uma teoria etnográfica da política. Rio de Janeiro: 7 Letras, 2006. 368 p.
}

\section{Letícia de Faria Ferreira* \\ Universidade Federal Rural do Rio de Janeiro - Brasil}

O livro escrito por Marcio Goldman faz uma observação antropológica da política mostrando as relações dos eleitores entre si, com o Estado e com os políticos, questões que vão sendo alinhavadas para o plano geral de discutir o funcionamento da democracia representativa. Uma pesquisa de campo de um considerável espaço de tempo - mesmo que descontinuamente foram 20 anos de contato - que permitiu ao autor abranger uma variedade de aspectos e dados a respeito do envolvimento político do movimento afro-cultural de Ilhéus (BA). As análises detalhadas do estudo de caso, aliadas a uma composição teórica bastante refinada, tornam o texto denso, sem perder a fluidez de um relato etnográfico.

Construindo uma análise crítica da própria postura do antropólogo em campo e refletindo sobre os atributos e significados de uma observação participante, o livro desdobra-se em pensar a teoria etnográfica e o trabalho do antropólogo em campo. Está em jogo no texto a possibilidade do antropólogo se deixar afetar pelas experiências do nativo. Discutindo atentamente as posições e controvérsias dos antropólogos em torno do ponto de vista nativo Goldman adota uma proposta onde trabalho de campo e etnografia deixam de ser pensados como simples processos de observação ou de formas de conversão (quando o antropólogo assume o ponto de vista do outro), ou ainda de transmutação em nativo, para serem pensados, como sugerem Deleuze e Guattari, como um devir. Esse devir pode ser explicado de forma mais sintética como um movimento pelo qual o sujeito sai de sua própria condição por meio de uma relação de afetos que consegue estabelecer com uma condição outra.

* Doutoranda do Programa em Desenvolvimento, Agricultura e Sociedade. 
Nessa perspectiva proposta, a abordagem leva em conta as teorias nativas da política. O professor e pesquisador do PPGAS/Museu Nacional discute, em sua introdução, as operações que a antropologia, ao entrar no campo dos estudos políticos, propõe-se a realizar; trata dos descentramentos feitos pela proposta da antropologia da política com relação aqueles que sempre foram os objetos privilegiados de estudos no campo da ciência política, como as instituições, partidos etc... (p. 28). Uma pergunta acompanha a etnografia do autor: será possível levar a sério o que essas pessoas têm a dizer, não apenas sobre religião ou sobre manifestações "afro-culturais", mas sobre a democracia?

Será, portanto, através de uma etnografia cuidadosa que Goldman adentra em terrenos nem sempre valorizados ou concebidos como relevantes na política e na democracia. Se as questões iniciais do campo apresentavam-se como que embaralhadas ao pesquisador - a afirmação dos membros do movimento negro de Ilhéus de que todos os políticos são iguais; a certeza de que nenhum resultado eleitoral será capaz de alterar o destino das pessoas mais desprovidas economicamente; o fato de que, em troca de pequenas retribuições materiais pessoas muito pobres são capazes de votar e apoiar aqueles mesmos que as exploram - o trabalho de campo e a perspectiva que adotada, capaz de perceber essas afirmações como um modo nativo de vivenciar a política, permitiram que isso pudesse ser analisado de modo positivo.

Afinado com a perspectiva de análise, denominada de antropologia da política, termo de Moacir Palmeira usado a partir de meados da década de 1990, Goldman exercita sua proposta de trabalho. A antropologia da política se propõe a abordar a política a partir do ponto de vista nativo, mas, como ressalta Goldman, isso não significa de modo algum ficar aprisionado nas elaborações locais, mas sim produzir teorias etnográficas que estejam livres de relações extrínsecas, ou seja, das categorias impostas por cientistas políticos, e evitando as abordagens efetuadas em termos negativos - aquelas que privilegiam as faltas, as ausências, ideologias ou manipulações. Deve ainda, recusar as falsas distinções entre o que é central ou periférico, ou seja, ao invés do pesquisador efetuar por si essa distinção, seria o caso de submetê-la à perspectiva nativa. (p. 41, 42).

Compondo um texto em que de modo simultâneo o trabalho etnográfico e as perspectivas teóricas adotadas dialogam, ao longo do livro, podemos observar que certos enfoques e as escolhas metodológicas permitiram a Goldman adentrar por caminhos que o levaram para dentro do movimento negro de Ilhéus (especialmente o bloco Dilazenze, da família de seu principal interlocutor, 
Marinho Rodrigues), e, ainda, para dentro das relações destes com o poder público local e também com os arranjos políticos eleitorais vivenciados pelos membros dos blocos. Para Goldman, as datas que são respectivas aos anos de política e constituem os títulos dos capítulos encontram sentido, pois são momentos diferenciados vividos pelos grupos observados. São tempos que por ocasião das eleições expressões, interesses e mecanismos de poder estão em funcionamento. O primeiro capítulo do livro, como os outros, situa-se em um ano eleitoral. Esse é respectivo a 2002, enquanto o segundo recua até 1996, quando a pesquisa teve seu inicio. Em uma espécie de reconstituição $a$ posteriori, através da memória de seus informantes, o terceiro capítulo aborda o ano que é crucial para os militantes negros - o ano eleitoral de 1992. Esse ano serve como uma espécie de nascedouro para as observações subseqüentes do envolvimento dos grupos afros com a política. ${ }^{1}$ Nesse movimento de recuos e avanços no calendário, o texto prossegue conduzindo sua descrição por mais três capítulos (um total de seis) perseguindo os passos dos blocos afros para construir um mapa de suas relações com a política. Será, portanto, o evento descrito no primeiro capítulo - nomeação de Marinho (uma das lideranças mais conhecidas do movimento afro-cultural de Ilhéus e informante de Goldman) para administrador do Memorial de Cultura Negra de Ilhéus - que dará uma espécie de liga ao conjunto do trabalho. O foco central é perceber através de uma antropologia da política as complexas relações entre o movimento negro e a política.

O processo de segmentação presente no interior do grupo afro leva o autor a uma revisão do uso dessa noção no pensamento antropológico (dos anos 1930 e 1940). Para Goldman, não se trata, por exemplo, de substituir o conceito de facção pelo de segmentaridade, mas uma complementação, pois as duas noções não ocupam o mesmo plano epistemológico (p. 174). Partindo das observações de campo da política e as relações com o movimento negro em Ilheús, o autor trata de experienciar as possibilidades do uso da noção de segmentaridade. Seguindo a proposição de Deleuze e Guattari de ampliação do conceito de segmentaridade, em seu estudo de caso o autor articula as cone-

1 Quando o antropólogo explicava que pretendia fazer uma pesquisa sobre política em Ilhéus, quase todos evocavam a eleição de 1992, por ter sido nesse ano que todos os blocos e grupos do movimento afro-cultural se reuniram em torno de uma candidatura para a prefeitura (p. 158).

Horizontes Antropológicos, Porto Alegre, ano 14, n. 29, p. 392-395, jan./jun. 2008 
xões e sobreposições de segmentação que são experienciadas pelos membros dos grupos afro-culturais em suas relações com o poder publico de Ilheús. As interpretações sobre o envolvimento político e as posições políticas do movimento negro são concebidas de modo "negativo" tanto pelas análises como pelos próprios integrantes dos grupos afros. Desse modo, a política para o movimento afro é vista como uma atividade negativa, capaz de acentuar relações assimétricas dentro da família ou do grupo. Assim, não é visto como de todo mal que alguém da família perca a eleição, pois desse modo não entra para outro plano hierárquico, como também não se tornará parte desse mundo moralmente condenável que é o da política. Essas observações revelam um processo em que coexistem sentimentos ambíguos com relação à política, pois os grupos, à mesma medida que anseiam por alguém que os represente, temem pela assimetria de poder que esse representante, caso eleito, terá com o grupo.

Serão observações com relação à assimetria que levam Goldman a pensar que certos mecanismos de diluição de poder seriam acionados pelos grupos afros. Essa questão é fundamental para se tentar entender a proposta do autor, que, pensando com Clastres (1974), diz:

Essa resistência em colaborar voluntariamente para o sucesso dos mecanismos de centralização do poder e essa recusa pratica em aceitar a introjeção de mecanismos de hierarquização assemelham-se, sem dúvida, ao que Pierre Clastres denominou "contra-Estado", esse conjunto de mecanismos que, nas sociedades “sem Estado”, impedem a constituição de um poder central ou coercitivo. (p. 296).

Goldman afirma que não temos nenhuma razão para supor que tais mecanismos funcionem apenas nas "sociedades sem Estado", posto que devemos reconhecer que estão bem vivos entre nós (p. 296).

Finalmente, as reflexões e o trabalho etnográfico apresentados pelo livro nos trazem os diversos retratos da política, o modo como é vivenciada e como os seus desdobramentos estão implicados no funcionamento da democracia. $\mathrm{O}$ livro remete a uma visão geral da política a partir do particular, tendo como suporte as especificidades, matizes e percepções reveladas pelos moradores de Ilheús, membros do bloco afro Dilazenze.

\section{Referência}

CLASTRES, Pierre. La société contre l'État. Paris: Minuit, 1974. 